Boom juridisch

Postbus 85576

2508 CG Den Haag

T (070) 3307033

E info@bju.nl

www.boomjuridisch.nl

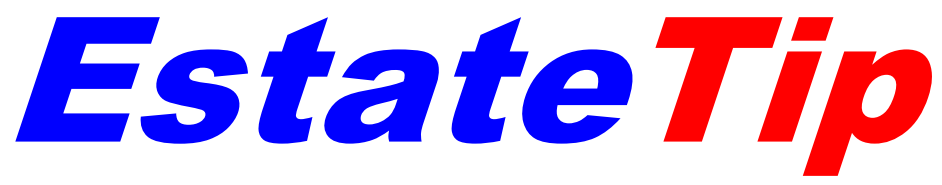

\title{
Vormvoorschriften bij afwijken van de Wvps
}

Ik vertel u niets nieuws met de mededeling dat sinds de inwerkingtreding van de Wet uitfasering pensioen in eigen beheer en overige fiscale pensioenmaatregelen (Stb. 2017, 115 ) het pensioen in eigen beheer (PEB) weliswaar is/wordt uitgefaseerd, maar dat dit nog niet betekent dat het PEB is 'verdwenen'. De directeur-grootaandeelhouder (dga) kan sinds juli 2017 niet langer in eigen beheer pensioen opbouwen. Vereenvoudigd weergegeven, heeft hij tot 2020 de keuze om het in eigen beheer opgebouwde pensioen af te kopen, om te zetten naar een oudedagsverplichting (ODV), dan wel te laten bestaan zonder dat verdere premiedotatie mogelijk is, artikel 38n lid 2 Wet LB 1964. Vandaag aandacht voor een scheiding waarbij sprake was van een PEB. Weliswaar is de scheiding in kwestie reeds in 2012 tot stand gekomen, maar de situatie is niet anders voor 'nieuwe' scheidingen waarbij het PEB zonder verdere opbouw is gehandhaafd.

Het betreft een in februari van dit jaar gepubliceerde uitspraak van de Rechtbank Gelderland van 17 oktober 2018 (ECLI:NL:RBGEL:2018:5766). Kort enkele feiten. Na 26 jaar met elkaar in wettelijke gemeenschap van goederen te zijn gehuwd, eindigt het huwelijk tussen de man (de dga) en diens echtgenote. Over het partner- en ouderdomspensioen is in het in juni 2012 overeengekomen convenant het volgende vastgelegd:

'Voor het in eigen beheer opgebouwde pensioen wordt een regeling getroffen na de juridische splitsing van [naam bedrijf].' (Curs. FH)

Kennelijk ging 'het treffen' minder soepel dan werd verondersteld, want in de procedure vordert de vrouw - onder verwijzing naar het arrest van de Hoge Raad van 9 februari 2007 (ECLI:NL:HR:2007:AZ2658)-- dat de man wordt veroordeeld tot het bewerkstelligen van afstorting bij een pensioenverzekeraar van het kapitaal dat nodig is ter dekking van het aan de vrouw toekomende deel van de door de man in eigen beheer opgebouwde pensioenaanspraken.

De rechtbank constateert dat de Wvps van toepassing is, dat vaststaat dat er voldoende liquide middelen beschikbaar zijn om de afstorting te kunnen realiseren en dat geen omstandigheden zijn aangevoerd die aan afstorting in de weg zouden staan. Wel overweegt de rechtbank dat de man wel heeft:

'4.3 [...] aangevoerd dat een nadere afspraak tussen partijen inhoudende dat binnen de holding een apart pensioenpotje voor de vrouw is gecreëerd, aan afstorting in de weg staat. Deze afspraak ligt volgens hem vast in correspondentie. Hierover is in 2014 nog gecorrespondeerd tussen partijen en hun toenmalige advocaten. De discussie is toen gesloten. Als de vrouw hier op terug wil komen, zal zij vernietiging van de nadere afspraken dienen te vorderen, aldus de man.' (Curs. FH) 
De man stelt in feite dat is gebruikgemaakt van de mogelijkheid van artikel 4 lid 1 Wvps:

'Bij huwelijkse voorwaarden of bij een bij geschrift gesloten overeenkomst met het oog op de scheiding kunnen de echtgenoten in afwijking van artikel 3, aanhef en onderdeel a van het eerste lid, overeenkomen het deel bedoeld in artikel 2, tweede lid, te bepalen op een door hen te kiezen vast percentage dan wel de in artikel 3, eerste lid, onder a, nader bepaalde periode te wijzigen. [...].' (Curs. FH)

Duidelijk, zowel het uitsluiten van de Wvps (art. 2 lid 1 Wvps) als het anderszins afwijken van de vereveningswet is gebonden aan vormvoorschriften. Dit vormvoorschrift betekent zo de rechtbank - dat men niet eens toekomt aan beoordeling van de vraag of de door de man gestelde nadere afspraak überhaupt is gemaakt, hetgeen overigens door de vrouw wordt betwist. De rechtbank is helder:

'4.5. Dit vormvereiste is in de wet opgenomen ter bescherming van de tot pensioenverevening gerechtigde echtgenoot, in dit geval de vrouw. Het tussen partijen gesloten convenant behelst geen afwijking van het wettelijk vereveningssysteem, nu hierin slechts bepaald is dat nog een nadere regeling zal worden getroffen. Van een afwijking vastgelegd in de huwelijkse voorwaarden of een bij geschrift gesloten overeenkomst is in dit geval geen sprake. De afspraak zou immers blijken uit correspondentie, maar het betreft niet een door partijen ondertekend stuk zo heeft de man ter zitting verklaard. Aan het vormvereiste dat de wet stelt, is daarmee niet voldaan. [...]' (Curs. FH)

De overwegingen van de rechtbank geven ook inzicht in de ratio van het vormvoorschrift:

'[...] Dat artikel 4 WVPS mede een vormvereiste omvat voor afspraken over het al dan niet afstorten van de pensioenaanspraken, is in lijn met de beschermingsgedachte achter die bepaling.' (Curs. FH)

En dus:

'Afstorting behelst een vorm van verevening in die gevallen dat sprake is van pensioen in eigen beheer. Het moet niet te eenvoudig zijn om af te wijken van de hoofdregel van verevening en afstorting, omdat dit de tot pensioenverevening gerechtigde echtgenoot aanzienlijk kan benadelen. Deze ziet zich dan geconfronteerd met een pensioenpot die feitelijk wordt beheerst door de exechtgenoot. De ex-echtgenoot bepaalt namelijk de gang van zaken binnen de rechtspersoon, waaronder het (beleggings)beleid. Om te voorkomen dat de echtgenoot afhankelijk blijft van dit beleid en van de solvabiliteit van de rechtspersoon die door de ex-echtgenoot wordt bestuurd, dient zij niet al te lichtvaardig afstand te kunnen doen van haar recht op verevening en afstorting van haar pensioenafspraken. Dus zelfs in het geval de nadere afspraak zoals gesteld door de man zou zijn gemaakt, dan nog maakt dit in dit geval niet dat de vrouw heeft berust in de situatie. Omdat niet aan het vormvereiste is voldaan, staat het haar vrij alsnog te verzoeken om afstorting.' (Curs. FH)

Bij dit alles een tweetal kanttekeningen. Het vormvoorschrift van artikel 4 lid 1 Wvps geldt uiteraard niet alleen voor dga's, maar voor alle afwijkende afspraken die binnen de Wvps zijn toegelaten (zie ook art. 57 lid 1 Pensioenwet, dat een vergelijkbaar vormvoorschrift kent). Denk bij afwijkende afspraken, onder meer, aan het uitsluiten van de wet of het overeenkomen van een afwijkend percentage of een afwijkende periode en de keuze tot conversie. Een overeenkomst daarover dient dan ook gepaard te gaan met de nodige waarborgen. Het vormvoorschrift is daar één van, evenals - vanzelfsprekend - de 
Belehrung door de begeleidende adviseurs. Ook past de uitspraak in het beeld dat uit de jurisprudentie naar boven komt over de geldigheid van per mail, telefoon, app, enzovoort gemaakte 'afwijkende' Wvps-afspraken. In zoverre behelst de uitspraak weinig nieuws. Opmerkelijk is wel dat de rechtbank de beschermende werking van het vormvoorschrift ruimer toepast dan tot heden wellicht kon worden verondersteld. De vraag kan immers worden gesteld of 'afstortafspraken' niet veel meer een uitwerking en nadere invulling van de verevening(swet) zijn, dan een afwijking van die wet. In het laatste geval zou (in de visie van de rechtbank) het vormvoorschrift op 'alle' afstortafspraken van toepassing zijn. Ziet men de afstortverplichting en afspraken daarover echter als een door redelijkheid en billijkheid ingekleurde regeling die pas aan bod komt indien en voor zover er daadwerkelijk wordt verevend, dan verbaast de uitspraak van de Rechtbank Gelderland. Interessant is dan ook of het oordeel van de rechtbank een fundamenteel (nieuwe) zienswijze behelst, dan wel of men meer werd 'geleid/gestuurd' door procestechniek (uit de overwegingen blijkt bijvoorbeeld niet of de man i.c. zelf heeft gesteld dat een afwijkende vereveningsafspraak in de zin van art. 4 lid 1 Wvps is gemaakt) tot dit oordeel is gekomen.

Tot volgende week!

Mr. F.M.H. Hoens

Radboud Universiteit Nijmegen

ScholsBurgerhartSchols

\section{Boomjuridisch}

www.scholsburgerhartschols.nl www.boomjuridisch.nl

(C) 2019 Boom juridisch | ScholsBurgerhartSchols

Hoewel de uiterste zorg is besteed aan de inhoud van EstateTip Review aanvaarden de uitgever en de redactie geen aansprakelijkheid voor onvolledigheid of onjuistheid. 